\title{
Analysis of Malaysian Regional Quality-of-Life and its Policy Implications
}

\author{
Mohammad Abdul Mohit \\ Kulliyyah (Faculty) of Architecture and Environmental Design \\ IIUM, Jalan Gombak, Kuala Lumpur, Malaysia \\ mamohit@iium.edu.my / mohd.mohit@gmail.com
}

\begin{abstract}
The Malaysian Quality of life Index (MQLI) has improved by 7.0 points during 1990-2000 and further to another 11.9 points from 2000 to 2010. Nevertheless, it is anticipated that the improvement in the QOL has not been uniform across the states in the country. Therefore, a study need arises to investigate the regional variations in the $\mathrm{QOL}$ in the country so that future policies may be directed towards removing the disparity in socioeconomic development of the country. Objective measurements of social, economic, physical and environmental data at the regional level have been analyzed to investigate regional variations in $\mathrm{QOL}$.
\end{abstract}

Keywords: Quality of life; Regional variation; Objective measurement; Economic growth

eISSN 2398-4279 @ 2018. The Authors. Published for AMER ABRA CE-Bs by e-International Publishing House, Ltd., UK. This is an open access article under the CC BY-NC-ND license (http://creativecommons.org/licenses/bync-nd/4.0/). Peer-review under responsibility of AMER (Association of Malaysian Environment-Behaviour Researchers), ABRA (Association of Behavioural Researchers on Asians) and cE-Bs (Centre for EnvironmentBehaviour Studies), Faculty of Architecture, Planning \& Surveying, Universiti Teknologi MARA, Malaysia.

DOI: https://doi.org/10.21834/ajqol.v3i9.73 


\subsection{Introduction}

Malaysia has experienced a period of high economic growth over the last few decades, propelling the nation from an agricultural and commodity-based economy to become a prosperous thriving middle-income nation (EPU, 2010, p. 34). The per capita GDP of the country has increased twenty-fold from RM1395 (US Dollar 489) in 1970 to RM29661 (US Dollar 9693) in 2011. This growth has helped improve the quality of life for Malaysians and supported widespread advances in education, health, infrastructure, housing and public amenities. Commensurate with this economic development, the Malaysian Quality of life Index (MQLI) has improved by 7.0 points during 1990-2000 and further to another 11.9 points from 2000 to 2010 (EPU, 201). Nevertheless, it has been remarked (Mohit, 2009) that this national development has not been uniform across the fourteen states/ regions of the country. Moreover, it is anticipated that the improvement in the national QOL has not been uniform across the fourteen regions/ states in the country. Therefore, a study need arises to examine the regional variations in the QOL that have occurred in the country so that future policies may be directed towards reducing the disparity in socioeconomic development of the country across the regions.

\subsection{Aim, objectives and hypothesis of the study}

The aim of the study is to construct QOL indices for the fourteen states of Malaysia and analyze their variations to arrive at policy suggestions. The study embarks on following objectives -

A. Construct the regional QOL based on the state level domains and indicators of socioeconomic development.

B. Investigate the regional differences of $\mathrm{QOL}$ by the states of Malaysia.

C. Identify the components/domains and indicators of QOL responsible for the differences.

D. Formulate policies to reduce interregional disparities in the $\mathrm{QOL}$

The general hypothesis framed for the study is - the regional QOL improvements resulting from the socioeconomic development of the country, has not been uniform across the different states of Malaysia.

Objective regional level data of social, economic, physical and environmental conditions, available from secondary sources, have been analyzed through adopting appropriate techniques to test the hypothesis and fulfill the objectives of the study.

\subsection{Qol study framework}

Based on the availability of secondary data, the present study has adopted a QOL framework which consists of 7 domains. These are - communication and recreation, economic condition, educational facilities, environmental condition, health facilities, public safety and social condition. A total of 35 indicators belonging to the 7 domains have been used in this study as shown in Fig.1. 


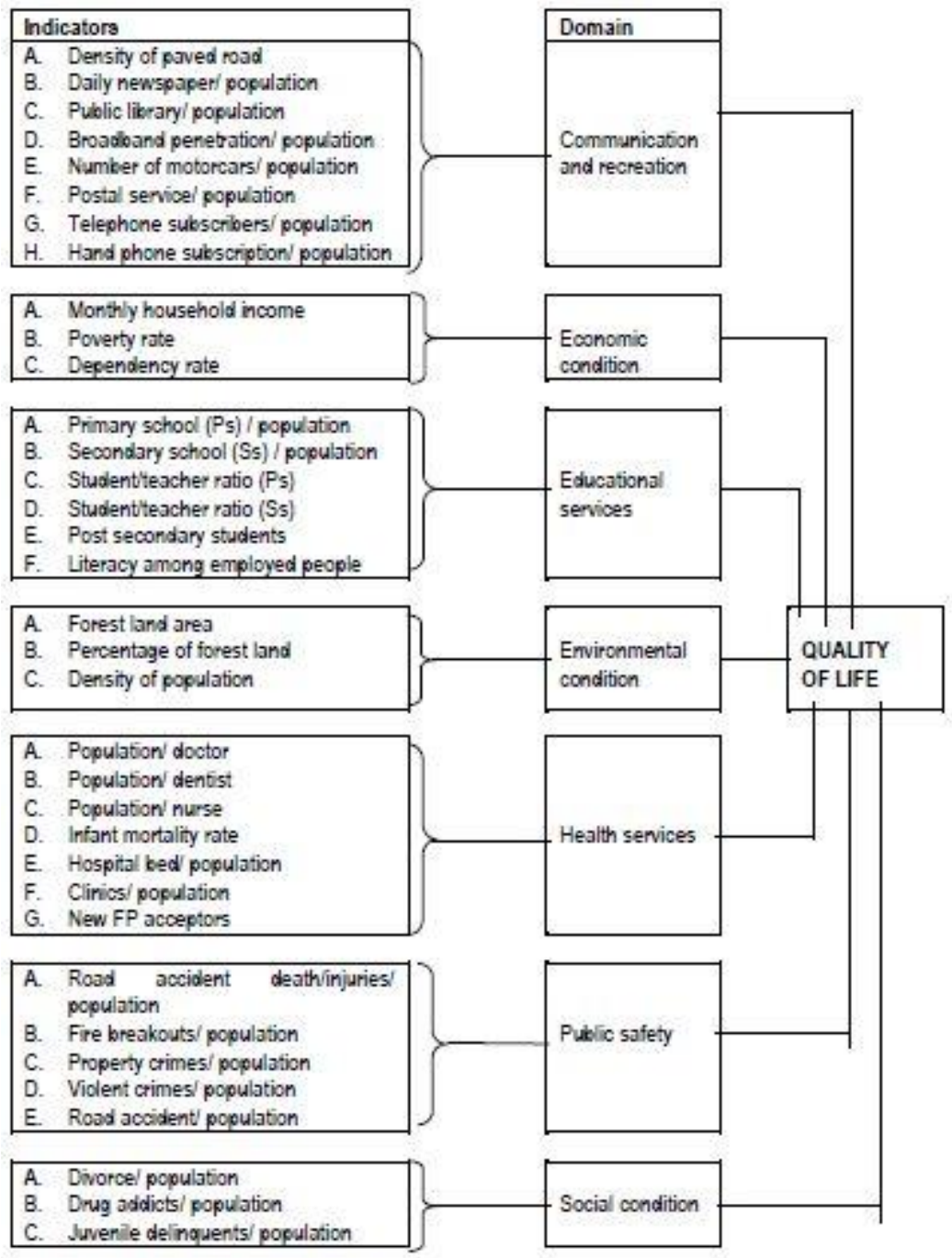

Figure 1: QOL Domains and indicators used in the study.

\subsection{Literature Review}

\subsection{Territorial Social Indicator}


QOL research perspective for regional analysis by using objective measurement owes its origin to the social indicators movement which incorporated an explicitly spatial perspective (Stimson and Marans, 2011). As mentioned by Smith (1973 referred in Stimson and Marans, 2011), the geographic notion of social well-being deals with the condition with areal variations. Hence, a term 'territorial social indicator' has been used to refer to approaches that explicitly subsume what Smith had referred to as the concepts of 'local', 'regional' and 'urban' indicators (Stimson and Marans, 2011). The idea of territorial social indicators involving spatially disaggregated analysis was part of the social indicators movement which began during the 1960s in the USA. According to Wilson (1969, mentioned in Stimson and Marans, 2011), the development of interest in territorial social indicators in the USA was encouraged because of the dominant roles local and state governments used to play and the immediate impact they had on peoples' QOL. Similarly, in the UK, there was an increasing interest in territorial social indicators from the early 1970 s when the Central Statistical Office (1970) began to map regional disparities in social conditions in the country, highlighting spatial concentrations of social problems.

\subsection{Empirical Studies}

Studies using QOL for regional analysis are wide-ranging cross-culturally. Marans and Byoung-Suk (2011) used QOL to analyze the quality of community life across the many and diverse administrative areas comprising the metro Detroit area. Stimson et al, (2011) report on the changes that have occurred between 1997 and 2003 in residents' perceptions of QOL in the Brisbane-South East Queensland Region of Australia. Turkoglu, Bolen, and Terzi (2011) provided an objective assessment of community life through an investigation of how different types of housing affect QOL in the city of Istanbul in Turkey. Oktay and Rustemli (2011) investigated QOL and neighborhood satisfaction in Famagusta in North Cyprus, Turkey. Keul and Prinz (2011) by relying on GIS support examined QOL at the neighborhood level in the city of Salzburg, Germany. McCrea, Western and Tung-Kai (2011) examined differences of QOL at metropolitan, regional, and rural areas in Queensland, Australia, with respect to four specific attributes of the physical, and social urban as well as overall QOL. Messer and Dillman (2011) examined subjective satisfaction across a range of 14 QOL indicators and their changes over 37 years in the State of Washington in the USA. ByoungSuk and Marans (2011) report the findings from the analysis of subjective QOL survey data at different geographic scales to reflect the different types of settlements that constitutes a region, in this case the Detroit metro area.

Stimson and Marans (2011) reviewed the approaches used in the studies of objective QOL and QOUL based on the analysis of secondary aggregate data. Mulligan and Carruthers (2011) investigated the relationship between urban amenities, QOL and regional development by drawing empirical studies from the USA and Europe. Guhathakurta and Cao (2011) used a series of objective indicators of QOL to examine the variations in objective QOL across Phoenix, Arizona. McCrea used 2003 South East Queensland (SEQ) data to focus on using spatial clustering of objective indicators to identify different 'types' of subjective QOL relating to the residential locations (neighborhoods) of the survey 
respondents. Chhetri, Stimson, and Western (2011) applied GIS tools to arrive at the regionwide patterns of QOL dimensions across the SEQ region of Australia.

In Malaysia, most QOL studies have used subjective measurements based on respondents' perception. Dasimah (2009) used residents' views to examine their QOL in the 13 new towns constructed by the State Economic Development Corporation in Malaysia. Hafazah Abdul Karim (2012), examined four domains of QOL in low cost housing in Shah Alam. Sarina Muhamad Noor and Mohd Adli Abdullah (2012) studied quality of Work Life (QWL) in a multinational firm in Malaysia in which they found that job satisfaction, job involvement and job security have a significant relationship with QWL. Wan Ahmad Aizzat Wan Zaidi et al. (2012) studied QOL in patients with HIV infection and AIDS living in HYV shelters and found that although many patients were fearful about their future, but they agreed good QOL in the shelters. Saripah Abdul Latif et al (2013) investigated the effects of situational factor on recycling behavior in order to determine the QOL. Objective analysis of QOL is virtually absent in Malaysia, except EPU's MQLI. Therefore, there are research opportunities to QOL from an objective perspective in the country. The present study intends to contribute to this opportunity.

\subsection{Methodology}

The present study is based on the data published by the Department of Statistics Malaysia. The secondary data were calculated and standardized at the spatial level by using population-specific measurement. For example, for a particular indicator which varies across states, it is standardized at population specific scale (Table 1).

Table 1. Domains and indicators used in the regional QOL analysis.

\begin{tabular}{|lll|}
\hline Domain & \multicolumn{3}{l|}{ Indicators with their measurement } \\
\hline Communication and & A. & Kilometers of paved road per 10 square kilometer area \\
recreation & B. & Daily newspaper/ 100 population \\
& C. & Public library/ 1K population \\
& D. & Broadband penetration/ 100 household \\
& E. & Number of motorcars/ 1K population \\
& F. & Postal service/ 100K population \\
& G. & Telephone subscribers/ 1K population \\
& H. & Hand phone subscription/ 1K population \\
\hline Economic condition & A. & Monthly household income (RM) \\
& B. & Poverty rate (\%) \\
& C. & Dependency rate (\%) \\
\hline Educational facilities & A. & Population per primary school (Ps) \\
& B. & Population per secondary school (Ss) \\
& C. & Student/teacher ratio (Ps) \\
& D. & Student/teacher ratio (Ss) \\
& E. & Post-secondary students/10K population \\
& F. & Literacy rate among employed people \\
\hline Environmental condition & A. & Forest land area/ 10K population \\
& B. & Percentage (\%) of forest land \\
& C. & Density of population per sq km \\
\hline
\end{tabular}




\begin{tabular}{|lll|}
\hline Health facilities & A. & Population per doctor \\
& B. & Population per dentist \\
& C. & Population per nurse \\
& D. & Infant mortality rate \\
& E. & Hospital bed/ 100K population \\
& F. & Clinics/ 100K population \\
& G. & New FP acceptors/ 100K population \\
\hline Public safety & A. & Road accident death/ injuries/100K population \\
& B. & Fire breakouts/ 10K population \\
& C. & Property crimes/ 10K population \\
& D. & Violent crimes/ 10K population \\
& E. & Road accident/ 1K population \\
\hline Social condition & A. & Divorce/ 10K population \\
& B. & Drug addicts/10K population \\
& C. & Juvenile delinquents/100K population \\
\hline
\end{tabular}

Moreover, the calculation of individual indicator's index was done against the country value which is set at 100. The formula used is as follows:

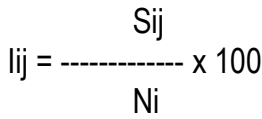

Where, lij = Index for ith indicator for jth state

$\mathrm{Sij}=$ Indicator ith value for the jth state

$\mathrm{Ni}=$ National indicator value.

For each component of QOL, indicator index values were summed and averaged. Similarly, the state QOL is obtained from the aggregate values of the domains over their number, in the 14 States including KL federal territory which is treated as another State. Putrajaya and Labuan were incorporated in Selangor and Sabah, respectively.

\section{Study Area}

Malaysia is a multi-ethnic and multi-cultural country with a federal constitutional monarchy. It consists of thirteen states and three federal territories and has a total land area of 329,847 square kilometers (127,350 sq mi) separated by the South China Sea into two regions Peninsular Malaysia and Malaysian Borneo. Land borders are shared with Thailand, Indonesia, and Brunei, and maritime borders exist with Singapore, Vietnam, and the Philippines. Kuala Lumpur is the capital city while Putrajaya is the seat of the federal government. In 2010, the population was 28.25 million, with 22.6 million living on the Peninsula. Since independence, Malaysia has one of the best economic performance records in Asia, with GDP growing at an average of $6.5 \%$ for almost 50 years. The economy has traditionally been fuelled by it's natural resources, but now it is expanding in the sectors of science, tourism, commerce and medical tourism. 


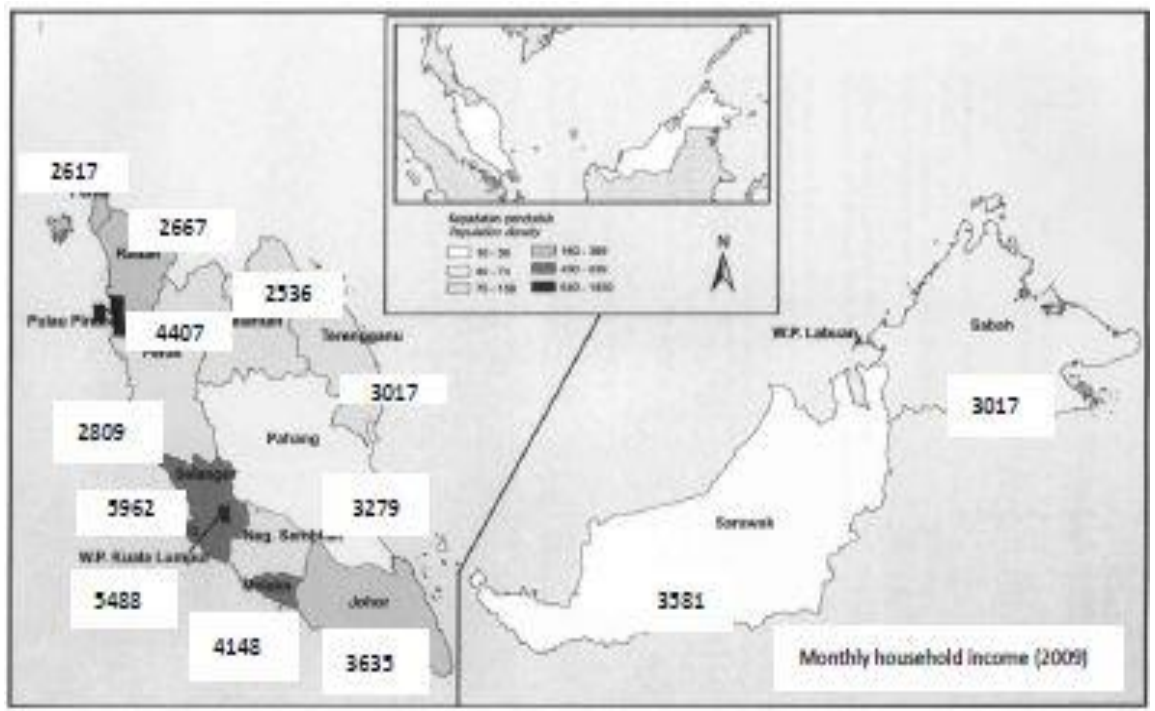

Figure 2: Map showing population densities and household monthly incomes by the States of Malaysia.

Over the last three decades, Malaysia has achieved a spectacular economic growth that has led to an increase of the per capita real GDP from RM 1,939 in 1970 to RM 13,546 in 2005. However, the increase has not been uniform across the 14 states of the country. The Third Malaysia Plan (1971) states "as a result of historical patterns of development, the different states and regions of Malaysia have shown very different rates of development, resulting in the unequal distribution of income, amenities and opportunities. Not only does output growth differ greatly between regions, there are also substantial regional variations in the growth of output per capita as well" (3MP, 1971). Even the National Physical Plan-I (2005) admitted that in Peninsular Malaysia, imbalances in economic growth exist between the West, and East Coasts - within the West Coast, imbalances also occur between the more developed states, such as Pulau Pinang and Perak, with the northern states like Kedah and Perlis. Reducing these imbalances is important towards enabling Malaysia to achieve the national integration (JPBD, 2005).

Table 2 shows that the fourteen Malaysian states are different in terms of area, population, GDP generation, employment distribution, housing condition and household income. These differences in the socio-economic indicators are a reflection of differing development potentials (both natural and man-made) which these states possess at present. These differential development potential also generates variations in the quality of life among the people of the states, because they are the manifestations of the state's socio-economic conditions or abilities of the states to generate income and employment and provide services. 
Abdul Mohit, M., / Asian Journal of Quality of Life (AjQoL), 3(9) Jan / Feb 2018 (p.11-23)

Table 2:. Selected State-level Socio-economic Indicators of Malaysia, 2010.

\begin{tabular}{|c|c|c|c|c|c|c|c|}
\hline State & $\begin{array}{l}\text { Population } \\
2010 \\
\text { (milion) }\end{array}$ & $\begin{array}{l}\text { Monthly } \\
\text { household } \\
\text { income } \\
\text { (RM) }\end{array}$ & $\begin{array}{l}\text { Area in } \\
\mathrm{sq} . \mathrm{km} \text {. }\end{array}$ & $\begin{array}{l}\text { State } \\
\text { GDP } \\
\text { (RM } \\
\text { million) }\end{array}$ & $\begin{array}{l}\text { State } \\
\text { employme } \\
\text { nt }(000)\end{array}$ & $\begin{array}{l}\text { Percent } \\
\text { age of } \\
\text { sound } \\
\text { housing }\end{array}$ & $\begin{array}{l}\text { Percentage } \\
\text { of } \\
\text { dilapidated } \\
\text { housing }\end{array}$ \\
\hline Johor & 3.31 & 3635 & 19210 & 51714 & 1306.3 & 95.1 & 4.9 \\
\hline Kedah & 2.00 & 2667 & 9500 & 19492 & 701.5 & 94.0 & 6.0 \\
\hline Kelantan & 1.67 & 2536 & 15099 & 9759 & 5052 & 86.5 & 13.5 \\
\hline Melaka & 0.77 & 4184 & 1664 & 15332 & 284.0 & 96.3 & 3.7 \\
\hline N. Semilan & 1.01 & 3540 & 6686 & 20605 & 386.5 & 97.8 & 2.2 \\
\hline Pahang & 1.53 & 3279 & 36137 & 25209 & 603.7 & 95.9 & 4.1 \\
\hline Perak & 2.46 & 2809 & 21035 & 29935 & 891.6 & 92.3 & 7.7 \\
\hline Perlis & 0.24 & 2617 & 821 & 3011 & 81.5 & 90.8 & 9.2 \\
\hline P. Pinang & 1.60 & 4407 & 1048 & 49510 & 689.8 & 95.3 & 4.7 \\
\hline Sabah & 3.21 & 3102 & 73631 & 31389 & 1306.1 & 84.0 & 15.9 \\
\hline Sarawak & 1.51 & 3581 & 124450 & 53448 & 977.5 & 91.5 & 8.5 \\
\hline Selangor & 5.10 & 5962 & 8104 & 120186 & 2095.3 & 97.8 & 2.2 \\
\hline Terenggand & 1.05 & 3017 & 13035 & 14762 & 390.3 & 86.2 & 13.8 \\
\hline WP Kuala & & & & & & & \\
\hline Lumpur & 1.72 & & & & & 96.8 & 3.2 \\
\hline (WPKL) & & 5488 & 243 & 77389 & 678.1 & & \\
\hline MALAYSIA & 28.25 & 4025 & 330803 & 521741 & 10897.4 & 93.6 & 6.4 \\
\hline
\end{tabular}

Source: Department of Statistics Malaysia, 2011.

\subsection{Findings and Analysis}

As mentioned earlier, the study uses 7 domains and 35 indicators for regional QOL analysis in Malaysia. The results of the analysis have been presented in Table 3 where it can be seen that in domain one- communication and recreation, 6 (43\%) of states which include Kedah, Kelantan, Pahang, Perak, Sabah and Terengganu, have indices below the national base $(=100)$ while the rest of the states is above the national base with Kuala Lumpur and $P$. Pinang showing relatively high values. On the economic condition domain, $7(50 \%)$ of the states are below the national base. These states are - Kedah, Kelantan, Perak, Perlis, Sabah, Sarawak and Terengganu, the rest of the states have performed above the national base, with Melaka, Selangor, Kuala Lumpur and N. Sembilan has significantly high economic performances. With regard to educational service domain, only 4 states such as Johor, P. Pinang, Selangor and Kuala Lumpur have index values less than the national average whereas a majority of states are marginally above the national base. A disappointing picture is notable with the environmental condition domain in which only three states - Pahang, Sabah and Sarawak are better off while the rest of the states are below the national base, with Kuala Lumpur and Melaka being in a critical condition. With respect to health service domain, only seven states - Melaka, N. Sembilan, Penang, Perlis, Terengganu, Perak and Pahang have indices above the national base, whereas the other states performed below the national level. On the public safety domain, eight states - Kedah, Kelantan, Pahang, Perak, Perlis, Selangor, Sarawak, Terengganu and Kuala Lumpur are better off compared to the other states. On the public safety domain, three States - N. Sembilan, Selangor, Melaka have serious problems compared to the other States. With regard to social conditions, six (43\%) 
States are better off than the rest eight (57\%) States. Social condition appears quite critical in Terengganu followed by Penang, Pahang and Kelantan States.

Table 3: Distribution of the indices of QOL domains by the States of Malaysia, 2010

\begin{tabular}{|c|c|c|c|c|c|c|c|c|}
\hline $\begin{array}{l}\text { Domain } \\
\text { Indices } \\
\text { State }\end{array}$ & $\begin{array}{l}\text { Index of } \\
\text { communica } \\
\text { tion \& } \\
\text { recreation }\end{array}$ & $\begin{array}{l}\text { Index of } \\
\text { economi } \\
\text { c } \\
\text { condition }\end{array}$ & $\begin{array}{l}\text { Index of } \\
\text { educatio } \\
\text { nal } \\
\text { services }\end{array}$ & $\begin{array}{l}\text { Index of } \\
\text { environmen } \\
\text { tal } \\
\text { conditions }\end{array}$ & $\begin{array}{l}\text { Index of } \\
\text { health } \\
\text { services }\end{array}$ & $\begin{array}{l}\text { Index } \\
\text { of } \\
\text { public } \\
\text { safety }\end{array}$ & $\begin{array}{l}\text { Index } \\
\text { of } \\
\text { social } \\
\text { conditi } \\
\text { on }\end{array}$ & $\begin{array}{l}\text { Average } \\
\text { composit } \\
\text { e index }\end{array}$ \\
\hline Johor & 110.10 & 162 & 95.80 & 39.3 & 89.7 & 91.2 & 102.4 & 98.6 \\
\hline Kedah & 96.20 & 74.8 & 103.05 & 44.8 & 90.2 & 116.1 & 182.3 & 101.1 \\
\hline Kelantan & 85.40 & 70.9 & 117.43 & 87.3 & 81.9 & 181.9 & 88.1 & 101.8 \\
\hline Melaka & 155.50 & 316.9 & 107.33 & 8.4 & 120.9 & 86.9 & 166.8 & 137.5 \\
\hline N. Sembilan & 154.20 & 243.4 & 111.00 & 41.4 & 118.8 & 73.1 & 82.2 & 117.7 \\
\hline Pahang & 93.60 & 123.5 & 119.58 & 170.8 & 100.4 & 140.3 & 79.1 & 118.2 \\
\hline Perak & 90.70 & 87.7 & 113.50 & 75.8 & 101 & 106.4 & 105.4 & 97.2 \\
\hline Perlis & 173.80 & 71.1 & 123.30 & 20.3 & 120.1 & 147.3 & 46.9 & 100.4 \\
\hline P. Pinang & 201.30 & 174.4 & 91.53 & 69.8 & 118.5 & 93.4 & 68 & 116.7 \\
\hline Sabah & 46.20 & 81 & 103.68 & 176 & 84 & 243.3 & 284.4 & 145.5 \\
\hline Sarawak & 112.70 & 83.2 & 120.53 & 209.7 & 85.2 & 205.7 & 300 & 159.6 \\
\hline Selangor & 143.80 & 266.3 & 71.53 & 25.5 & 92 & 83.5 & 151.5 & 119.2 \\
\hline Terengganu & 97.70 & 89.9 & 128.53 & 97.9 & 104.3 & 149.7 & 50.4 & 102.6 \\
\hline WPKL & 329.60 & 260.4 & 73.00 & 0.7 & 199 & 109.1 & 97.6 & 152.8 \\
\hline MALAYSIA & 100.0 & 100.0 & 100.0 & 100.0 & 100.0 & 100.0 & 100.0 & 100.0 \\
\hline
\end{tabular}

Source: Secondary data, 2013

Composite index calculated for each State portrays the overall QOL condition of the States) Two States - Johor and Perak are below the national index $(=100)$, whereas four States Kedah, Kelantan, Perlis and Terengganu are in marginal situations (Table 3). On the contrary, eight States - Kuala Lumpur, Sarawak, Sabah, Melaka, Selangor, Pahang, N. Sembilan and P. Pinang are above the national index. While comparing composite index with the economic condition of the States, it appears that a few States such as Sabah, Sarawak have low economic performance, but their $\mathrm{QOL}$ indices are satisfactory. This implies that QOL does not invariably depend on the economic performance of the States.

Fig.3 portrays the State-wise QOL domains and their index values. Johor has only three domains $(43 \%)$ - communication and recreation, economic condition and social condition with indices above the national value. Similarly, Kedah has also three domains - educational services, public safety and social condition in which the indexes are above the national value. Kelantan has two domains - educational services and public safety, with index values above the national level. Melaka has five domains - communication and recreation, economic condition, educational services, health services and social condition which have index values above the national level. N. Sembilan has four domains - communication and recreation, economic condition, educational services and health services where the indexes are above the national level. Pahang has five domains - economic condition, educational services, environmental condition, health services and public safety, in which QOL indexes are above 
the national level. Perak State has four (4) QOL domains - educational services, health services, public safety and social condition, in which the index values are above the national level. Perlis State has four (4) domains - communication and recreation, educational services, health services and public safety, where the indexes are above the national QOL value. P. Pinang State has three QOL domains with index values above the national level. Sabah State has four (4) QOL domains with index values above the national index. Sarawak State has five QOL domains with index values above the national level. These are communication and recreation, educational services, environmental condition, public safety and social condition. In Selangor State the index values for communication and recreation, economic condition, and social condition are above the national level. In Terengganu State the index values for educational services, health services and public safety domains are above the national indices. WP Kuala Lumpur has four (4) QOL domains - communication and recreation, economic condition, health services and public safety whose index values are above the national level.

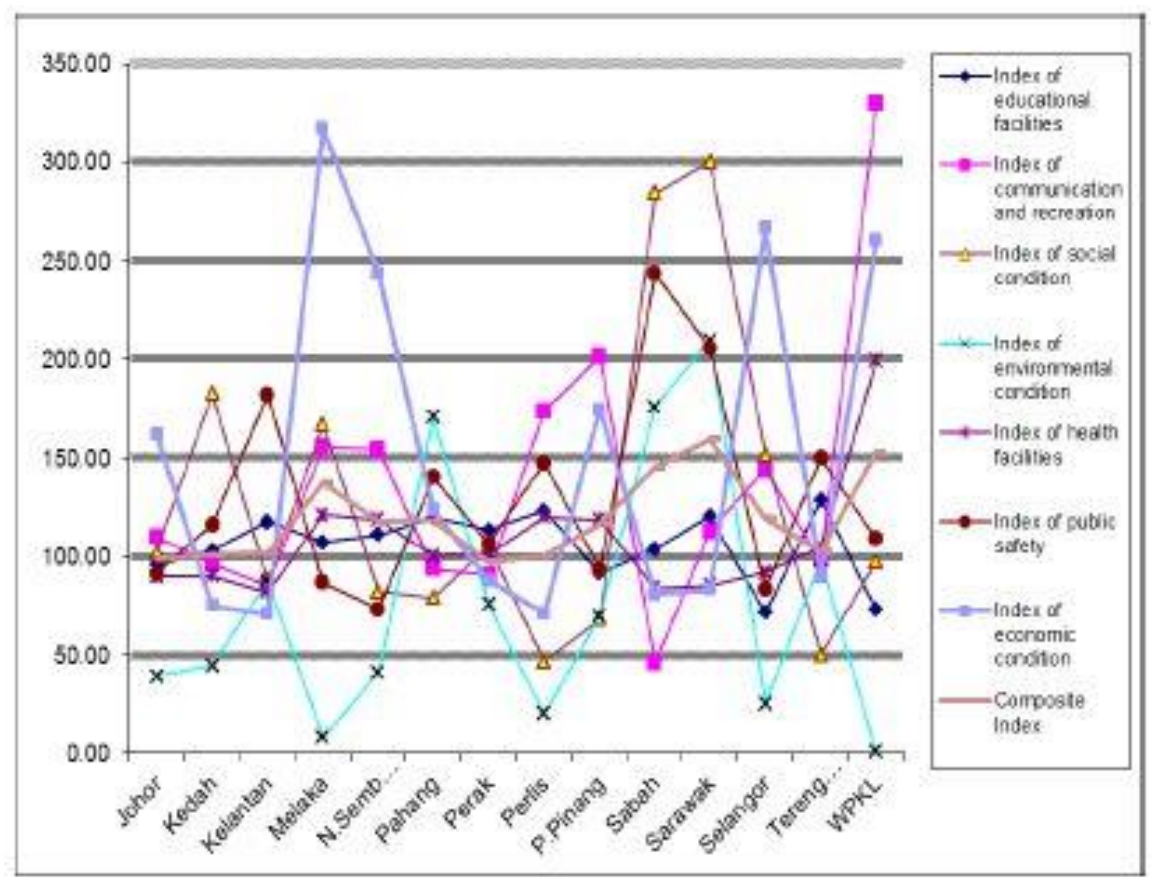

Figure 3. Graphical presentation of QOL domain indices by the States of Malaysia.

A correlation matrix was calculated in order to highlight on the contributory domains to State QOL, and the results are presented in Table 4. 
Table 4. Correlation matrix between $\mathrm{QOL}$ domains and composite $\mathrm{QOL}$ index

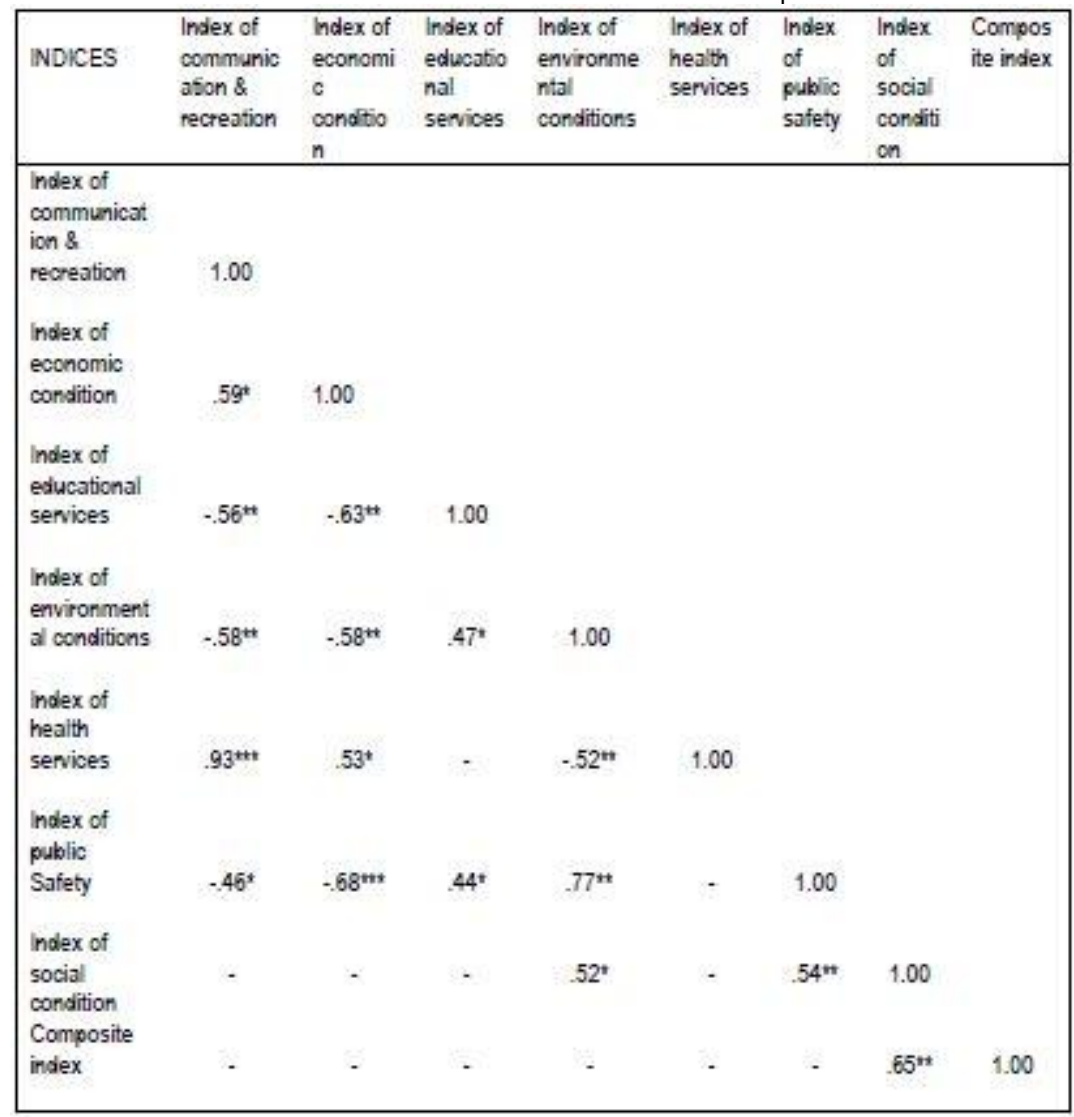

Source: Calculation based on Department of Statistics Malaysia data, 2010-2011 Notes: ${ }^{* *}$ Significant at .001 level; **Significant at .05 level; *Significant at .10 level.

The correlation result (Table 4) shows that the composite QOL index at the State level is significantly positively associated with social condition of the State. Furthermore, social condition is significantly positively correlated with the environment and public safety. Again, environmental condition is significantly positively correlated to educational services but negatively correlated with the economic condition and communication-recreation. Very paradoxical is the significant negative correlation between educational services and economic condition. Again, economic condition is significantly positively correlated with health services, but at the same time it is negatively correlated with public safety. Economic condition is positively associated with communication-recreation, while the latter is positively correlated with health services but negatively related to education and public safety. 
Therefore, it seems that State level QOL is associated with social condition, but not necessarily with economic conditions while social condition is positively correlated with environmental condition and public safety. Therefore, the main determinants of State QOL in Malaysia appear to be improvements in social condition, environmental condition and public safety.

\subsection{Conclusion}

This paper investigates the objective domains of the State $\mathrm{QOL}$ in order to test the hypothesis that there are objective variations of quality of life across the fourteen States of Malaysia. The finding of the study supports the hypothesis through the seven domains which have been analyzed by adopting indexing techniques. The findings of the paper suggest that in order to reduce differences in the interstate $\mathrm{QOL}$ and improve it as well, policy measures are necessary to enhance social condition, environmental condition and public safety. The indicators determining the social component are - divorce rate, drug addicts and juvenile delinquency. Hence, measures are necessary to reduce these rates. Again, environmental conditions can be improved through reducing pollution and enhancing citizen awareness. Similarly, public safety variables such as road accidents, crimes, fire breakouts should be brought under control in order to enhance State-level QOL. Therefore, the States of Malaysia should take active initiate towards improving the social, environmental and public safety conditions along with economic development for both reducing interstate differences of QOL, and improve them as well.

\section{References}

Dasimah Bte Omar (2009). Assessing Residents' Quality of Life in Malaysian New Towns. FPSU Publications. Malaysia: UiTM, pp.94-102.

Department of Statistics Malaysia (2010). State/ District Level Data Bank Malaysia 2010. Putrajaya: Department of Statistics.

Department of Statistics Malaysia (2009). Household Income and Basic Amenities Survey Malaysia 2009. Putrajaya: Department of Statistics.

Department of Statistics Malaysia (2011). Social Statistical Bulletin Malaysia 2010. Putrajaya: Department of Statistics.

EPU (2012). The Malaysian Quality of Life Index 2011. Putrajaya: EPU, Prime Minister's Department.

EPU (2011). Tenth Malaysia Plan 2011-2015. Putrajaya: EPU, Prime Minister's Department. 
EPU (1971). Third Malaysia Plan 1971-1975. Kuala Lumpur: EPU, Prime Minister's Department.

Hafazah Abdul Karim (2012). Low Cost Housing Environment: Compromising Quality of Life. Procedia Social and Environmental Studies, vol. 35, pp.44-53.

JPBD (2005). The National Physical Plan (2005-2010). Kuala Lumpur: JPBD.

Marans, R.W. and Stimson, R.J. (eds) (2011). Investigating Quality of Urban Life - Theory, Methods and Empirical Research. eBook. Springer Science+Business Media.

Mohit, M.A. (2014). Present Trends and Future Directions of Quality of Life . Procedia Social and Behavioral Sciences, vol. 153, pp.655-665.

Mohit, M.A. (2013a). Quality of Life in Natural and Built Environment - An Introductory Analysis. Procedia - Social and Behavioral Sciences, vol. 101, pp.33-43.

Mohit, M.A. (2013b). Objective Analysis of Variation in the Regional Quality of Life in Malaysia and its Policy Implications. Procedia - Social and Behavioral Sciences, vol. 101, pp.454-464. Mohit, M.A. and Nurul Nazyddah (2011). Social housing programme of Selangor Zakat Board of Malaysia and housing satisfaction. Journal of Housing and the Built Environment, 26 (2): 143-164.

Mohit, M.A., Mansor Ibrahim and Yong Razidah Rashid (2010). Assessment of residential satisfaction in newly designed public low-cost housing in Kuala Lumpur, Malaysia. Habitat International, 34(1): 18-27.

Mohit, M. A. (2009). Structural changes of the Malaysian economy and its spatial incidence on regional economic growth. PLANNING MALAYSIA - Journal of the Malaysian Institute of Planners, VII, 25-46.

Sarina Muhamad Noor and Mohamad Adli Abdullah (2012). Quality of Work Life among factory workers in Malaysia. Procedia Social and Environmental Studies, vol. 35, pp.739-45.

Wan Ahmad Aizzat Wan Zaidi et al. (2012). Quality of Life amongst HIV positive patients in Malaysian HYV Shelters. Procedia Social and Environmental Studies, vol. 35, pp.213-220. 